\title{
Geotouristic excursion to selected historical mining sites developed by Slovak and German miners in the Gelnica-Smolník region, Slovakia
}

\author{
Wycieczka geoturystyczna do wybranych miejsc historycznej eksploatacji złóż rud \\ przez słowackich i niemieckich górników w rejonie Gelnicy-Smolníka, Słowacja
}

\author{
Pavol Rybár, Tibor Sasvári, Ladislav Hvizdák, Jana Hvizdáková, Bartolomej Baláž \\ Prof. Ing. Pavol Rybár, PhD., Ing. Ladislav Hvizdák, Ing. Jana Hvizdáková, Ing. Bartolomej Baláž, PhD. \\ Institute of Geotourism, Faculty BERG, TU Kosice, Slovakia
}

Prof. Ing. Tibor Sasvári,PhD., Institute of Geosciences, Faculty BERG, TU Kosice, Slovakia
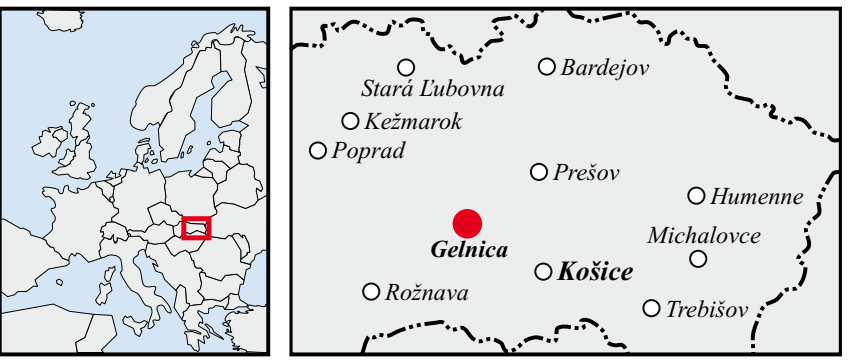

Abstract: The following paper summarizes the history of Gelnica, Smolnik and Rožñava gold, silver, copper and iron orefields in Eastern Slovakia, which have been mined since the Medieval ages by of Slovak and German miners. In Gelnica, where mining operations date back to the XIIth century, massive quartz-sideritechalcopyrite veins with $\mathrm{Fe}$-dolomite, pyrite and tetrahedrite (with silver) cut Lower Devonian phyllites and porphyroids. In Smolnik, where copper mining has commenced in the first half of the XIIIth century followed by gold, then silver and iron ore exploitation, 10-11 pyrite-chalcopyrite ore horizons are hosted in Silurian phyllites. In Rožn̆ava mining operations for iron, silver, gold and copper ores have been known since the XIIIth century and have lasted until 1992. Over 40 ore veins discovered in this field contain mostly siderite although quartz-siderite-sulphide paragenesis with Ag-bearing tetrahedrite was also observed. In all three mining districts there are numerous objects of mining heritage and other valuable historical monuments, reflecting the wealth of old Slovak mining towns.

Key words: History of mining towns, Gelnica, Smolnik, Rožňava, exploitation of precious and nonferrous metals

Treść: Artykuł podsumowuje historię eksploatacji złóż rud złota, srebra, miedzi i żelaza w Gelnicy, Smolniku i Rožňavie we Wschodniej Stowacji, które wydobywali od średniowiecza górnicy stowaccy i niemieccy. W Gelnicy, gdzie roboty górnicze rozpoczęto w XII w. wystęuja żyly kwarcowo-syderytowo-chalkopirytowe z niewielkq ilościa dolomitu żelazistego, pirytu i tetraedrytu zawierajacego srebro. Przecinajq one dolnodewońskie fyllity i porfiroi$d y$. W Smolniku, gdzie wydobywano miedź już w pierwszej połowie XIII w., a następnie eksploatowano złoto, srebro i rudę żelaza, $w$ fyllitach wieku sylurskiego zalega 10-11 horyzontów rudnych z pirytem i chalkopirytem. W Rožñavie rudy żelaza, srebra, złota i miedzi byly eksploatowane od wieku XIII do roku 1992. Znajduje się tutaj ponad 40 zył kruszcowych zawierajacych głównie syde$r y t$, chociaż znana jest także parageneza kwarc-syderyt-siarczki ze srebronośnym tetraedrytem. We wszyskich trzech okregach górniczych znajduje się wiele obiektów historycznego dziedzictwa górniczego, a także inne, cenne zabytki historyczne, dokumentujace bogactwo dawnych stowackich miast górniczych.

Slowa kluczowe: Historia miast górniczych, Gelnica, Smolnik, Rožňava, eksploatacja metali szlachetnych i nieżelaznych

\section{Introduction}

The Faculty BERG of the Technical University in Kosice, Slovakia organized a specialized meeting in order to follow the steps of Slovak and German miners in the historical ore mining districts of Gelnica, Smolník and Rožňava.

The meeting has lasted for two days: on the first day a ceremonial session was held of mining industry and mining universities representatives. About forty participants from Slovakia, Czech Republic, Germany and Hungary attended the meeting, including the past President of the Slovak Republic, Dr. Rudolf Schuster (Fig. 1,2) as well as the mayors of the Spiš and the Gemer regions. On the next day the program included visits to the sites of common history of Slovak and German miners working in Gelnica, Smolník and Rožňava districts (Fig. 3b).

The second-day tour was planned as a full-day trip for all the participants aimed to emphasize the importance of documenting the historical mining region of European value.

The first part of the tour led from Gelnicá to Žakarovce. The participants were carried in two special Avia off-road vehicles. After visiting Žakarovce and Gelnicá surroundings the participants were taken by buses to Smolník and surroundings where they visited the Teresian tunnel. Then, lunch was served in a restaurant in Smolník. After lunch the trip continued from Úhorná to Rožňava. Late afternoon the partici-

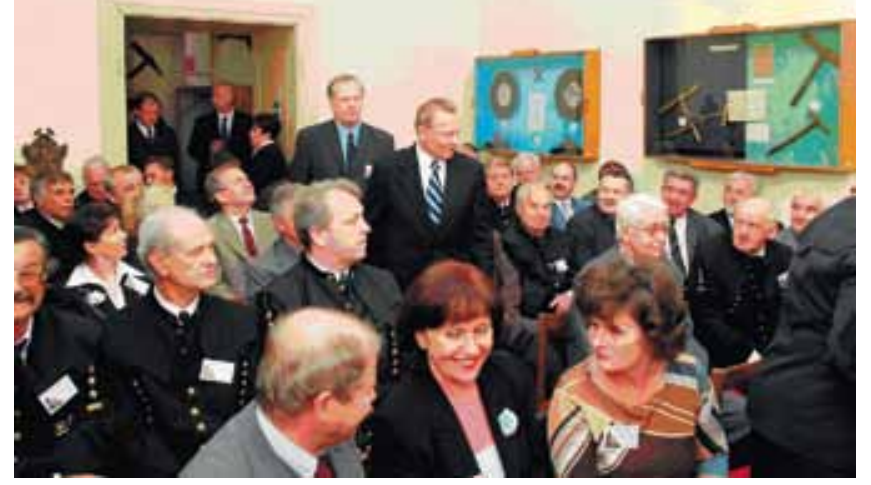

Fig. 1. The arrival of the President Dr. Rudolf Schuster at the meeting, photo T. Sasvári • Prezydent dr Rudolf Schuster przybywa na spotkanie, fot. T. Sasvári 


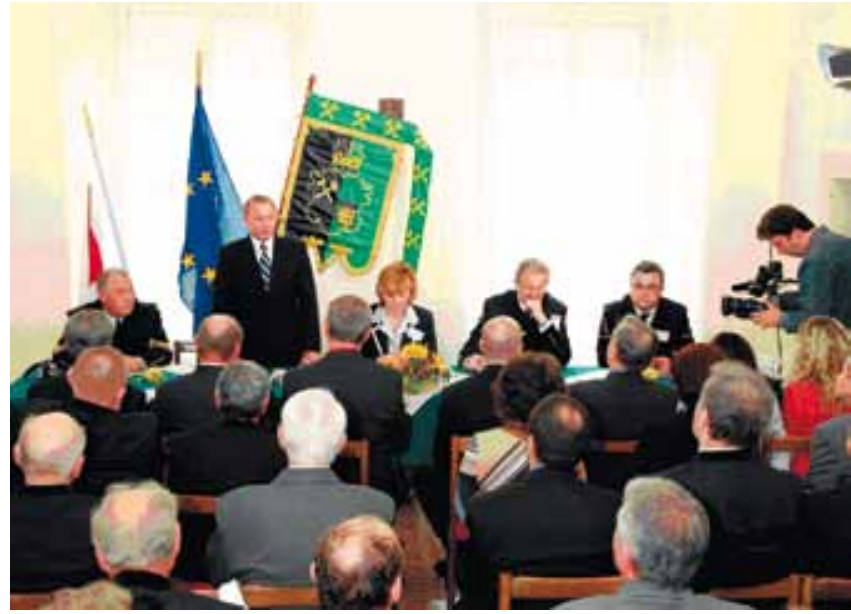

Fig. 2. President Dr. Rudolf Schuster speeks to the participants, photo T. Sasvári • Prezydent dr Rudolf Schuster przemawia do zebranych, fot. T. Sasvári)

pants returned to Gelnicá where the "šachtág" - a traditional, historical ceremony of admission to the miners' community - was performed.

\section{Geological setting}

\section{Rožňava}

In the Rožňava orefield, which covers some $48 \mathrm{~km}^{2}$, as many as 42 ore veins were discovered from which 7 veins accumulated 100,000 tons of ore reserves (Grecula et al., 1995). A morphologically prominent ridge of Košaricko-Turecká-Tri vrchy-Rakoš divides the Slana River and the Čučmiansky Creek valley into three parts. The western part of the Turecká massif is built mostly of porphyroids (metapaleorhyolites) whereas its northern slopes include the phyllitic member and the so-called "bottom volcanic member". The southern slopes are formed by sandstones and slates of Permian Gočaltov Unit. East from the Slana River, towards Čučma, most of the flysch members emerge (metapsammites and phyllites) of the Lower Paleozoic Smolnik Formation (Fig. 3b).

In the Rožňava orefield the veins contain predominantly siderite whereas quartz-siderite-sulphide paragenesis is less common and occurs merely in some particular veins (ArturTerezia, Sadlovsky, Štefan, Kliment, Augusta and Siedma žila). The Mária quartz-siderite-sulphide vein located under the Tri vrchy Hill hosted some amounts of tetrahedrite which contained up to $9.36 \mathrm{wt} . \%$ of $\mathrm{Ag}$.

\section{Gelnicá}

The area of Gelnicá and Slovinky hosts three significant vein zones: slovinská, gelnická and Zláta žila (Golden Vein) - Helcmanovsky žilnik. The gelnická zone hosts the Križová, Gelnická, Nadložná gelnická and Nová gelnická veins. These massive, quartz-siderite-chalcopyrite veins penetrate through the Lower Devonian phyllites and porphyroids (metapaleorhyolites) of the Drnava Formation within the Gelnicá Unit (Fig. 3b).

The most important vein mineral is quartz. Coarse-crystalline siderite is less common (in the Gelnická vein the quartz/ siderite ratio is 3:1) and the accompanying minerals are: ankerite, Fe-dolomite and calcite. Among sulphides dominant is disseminated or massive chalcopyrite with some pyrite and tetrahedrite, the latter containing $0.4 \mathrm{wt} \% \mathrm{Ag}$, up to $12.6 \mathrm{wt} . \%$ $\mathrm{Hg}, 0.9-7.6$ wt.\% Fe and 1.1-5.3 wt.\% Zn (Pauliš and Duda, 2002).

Another important ore vein zone was located in the vicinity of Žakarovce. The E-W-trending zone was $5 \mathrm{~km}$ long and 40-50 m thick, and included five interconnected orebodies. The main ore mineral was siderite accompanied by gangues: Fe-dolomite and quartz. Rare sulphides were pyrite, chalcopyrite and tetrahedrite. The ore graded 32-35 vol.\% Fe, 0.1-0.2 vol.\% $\mathrm{Cu}$ and $8-12$ vol. $\% \mathrm{SiO}_{2}$.

\section{Smolnik}

The Smolnik pyrite-chalcopyrite deposit is located in the central part of the Gemerides. The thrust-fold structure is hosted in Silurian epi-metamorphic complex belonging to the Hnilec (green phyllites) and Betliar (black phyllites) formations separated by a basalt-keratophyre horizon. The east-west-trending, 4-km-long orebody dips at high angle $\left(70^{\circ}\right)$. The highestgrade mineralization continues down to $250 \mathrm{~m}$ depth below surface. The orebody comprises 10-11 horizons of pyrite-chalcopyrite ore defined by Cu cut-off values (Fig. 3b).

The principal ore minerals are fine-crystalline to massive pyrite (20-90\%) and chalcopyrite. Depending on $\mathrm{FeS}_{2}$ content, the massive, stripped and disseminated ore varieties were distinguished. Chalcopyrite occurs in all these ore varieties. Characteristic feature is the high content of Se in pyrite (up to $200 \mathrm{ppm}$ ) and in chalcopyrite (up to $512 \mathrm{ppm}$ ).

\section{The history of the Upper Ugrian mining towns}

Both the business and the common economic interests led to the alliance of five, free, royal towns in the Eastern Slovakia: Košice, Levoča, Bardejov, Prešov and Sabinov. This union, known under the name of Pentapolitana or Pentapolis, was definitely established in the second half of the XVth century.

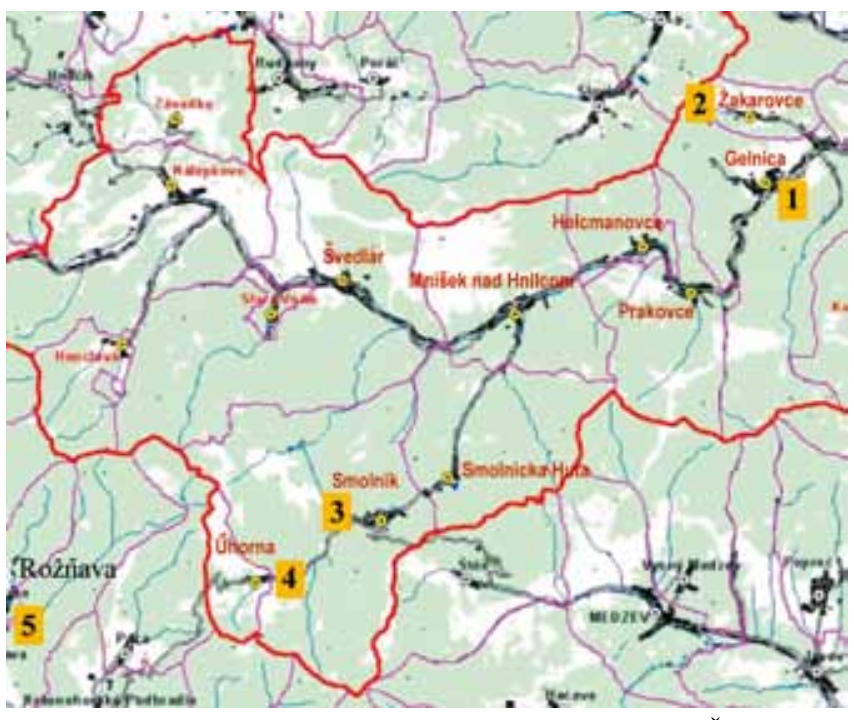

Fig. 3a. Excursion map. Visited sites: 1 - Gelnica, 2 - Žakarovce, 3 - Smolník, 4 - Uhorná, 5 - Rožňava • Mapa wycieczki z zaznaczonymi punktami: 1 - Gelnica, 2 - Žakarovce, 3 - Smolník, 4 - Uhorná, 5 - Rožňava 


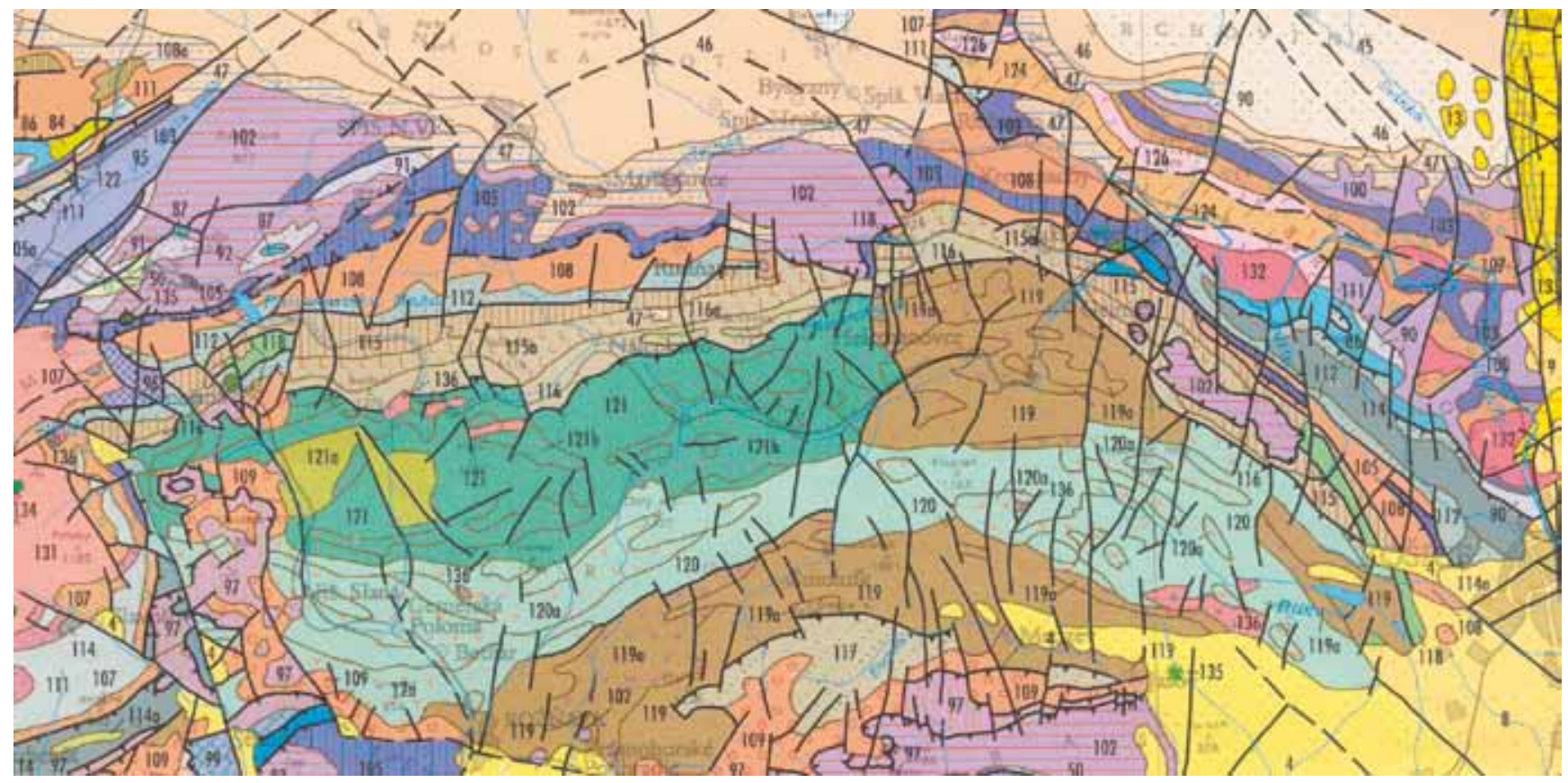

The association played an important role predominantly in the transit trade due to the control of the important crossroads of north-south- and west-east-trending trade routes. The leading position was held by the city of Košice where regular meetings of the five towns representatives were held. Well-organised intelligence service of the Pentapolis and its foreign contacts were commonly used by monarchs, royal ministers and aristocracy.

There were very tight connections and good cooperation between the Pentapolis and the Association of Mining Towns in the Eastern Slovakia, well-known under the name of "Upper Ugrian Mining Towns" (Civitates Montanae Partium Superiorum). At the inaugural meeting held in 1487 at the Royal Chamber in Košice, it was stated that, according to an old custom and law, the representatives of mining towns were obliged to take seats and to vote in the following order: Gelnica, Smolník, Rudabánya, Jasov, Telkibánya, Rožňava, Spišská Nová Ves (Rudabánya and Telkibánya are recently in the territory of Hungary). The rank, as well as the importance of towns were determined not only by the history and the range of privileges, but also by the value of mining production. The Agreement and the statutes were approved in 1498 by the Monarch through the highest non-commissioned count Matej Tengeler from Lichtenfeld, who signed the town protocols of all mining towns. He also confirmed the validity of the Gelnica mining law.

\section{Mining history \\ of the Gelnica - Smolník area}

The memory is still alive of the Eastern Slovakia mining fields, where noble metals (gold and silver), non-ferrous metals (particularly copper) as well as iron ores were produced. At Smolník the annual production in the first third of the XVth century was 182 tons of copper. As early as in the XIVth century, so-called "Spiš copper" dominated all the markets

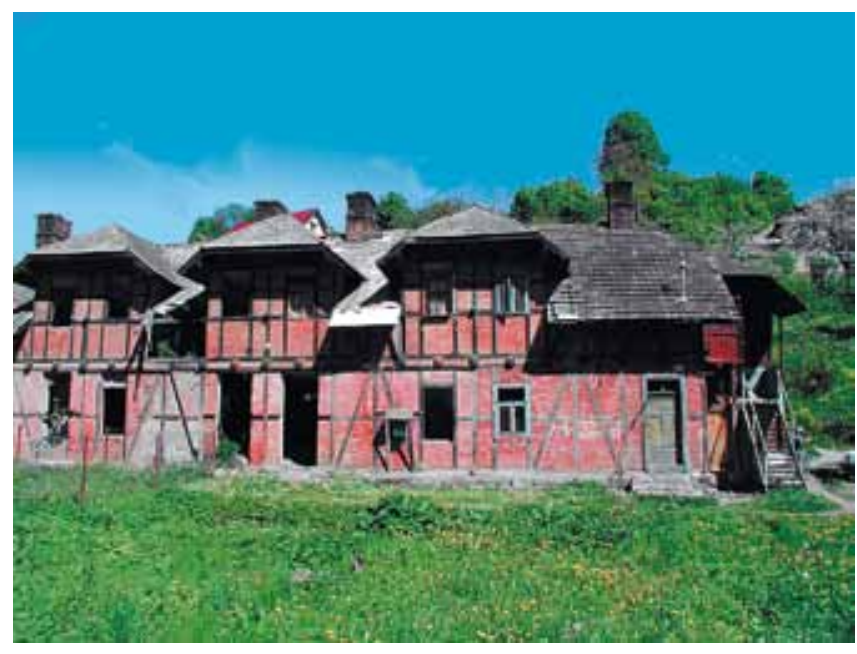

Fig. 4. Žakarovce (neighbourhood of Gelnica) mining ghost village, photo T. Sasvári • Opuszczone miasteczko górnicze Žakarovce (w sąsiedztwie Gelnicy), fot. T. Sasvári

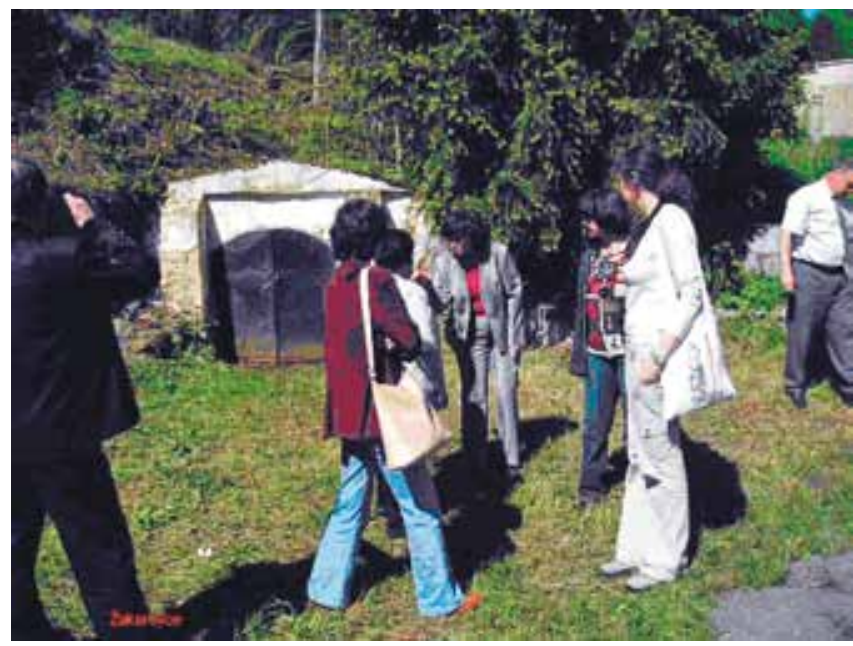

Fig. 5. Entrance to the Volhelm IV gallery at Žakarovce, photo St. Vassová • Wejście do sztolni Volhelm IV w Žakarovcach, fot. St. Vassová 


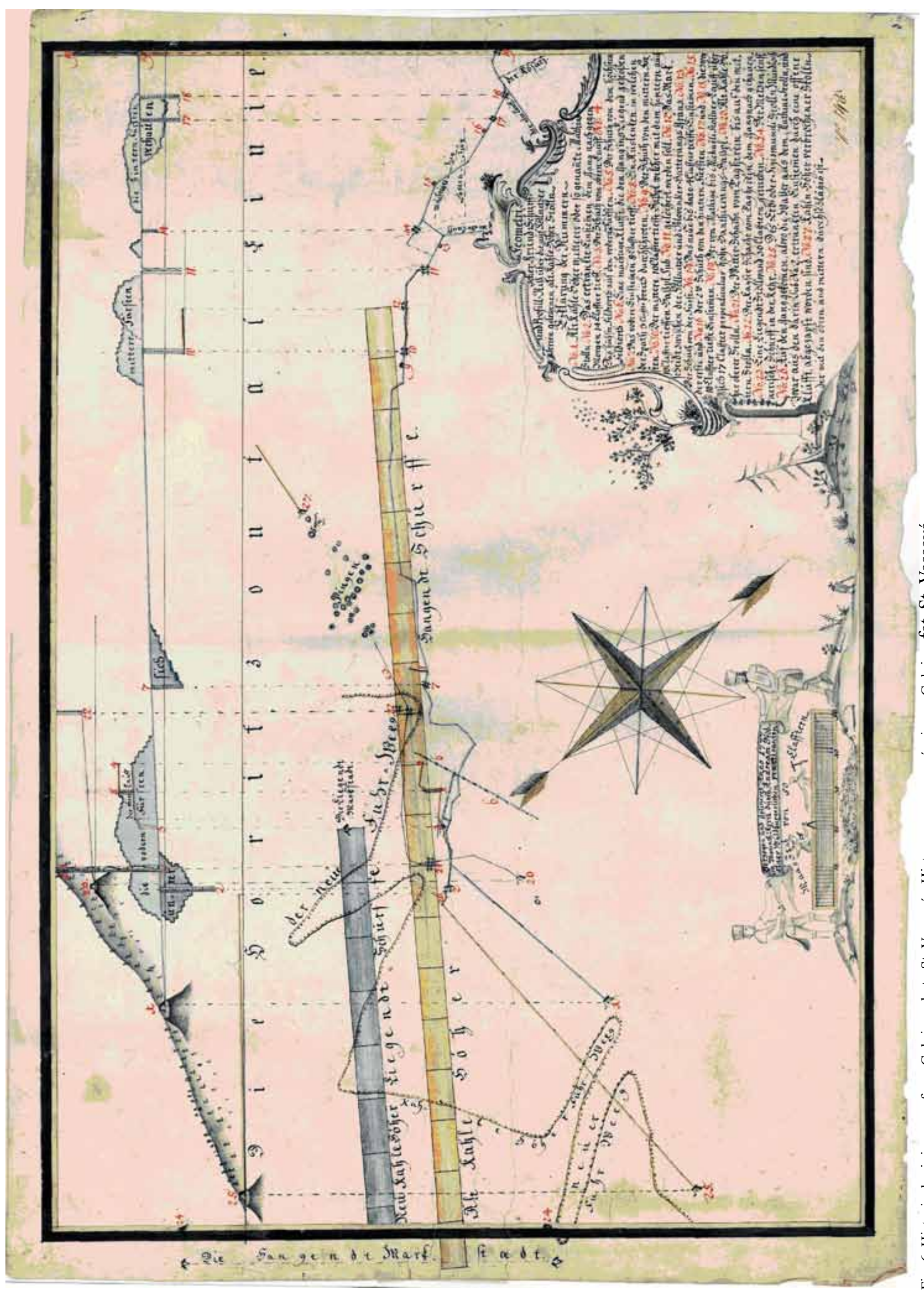




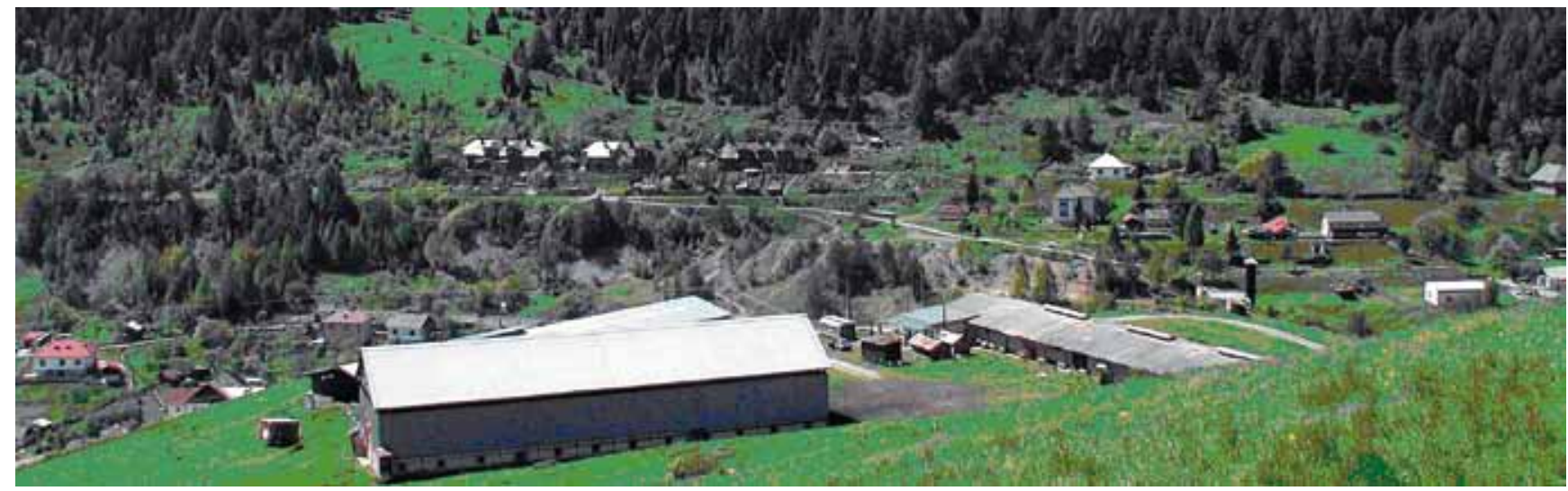

Fig. 7. Mining dumps and preserved mine constructions in the central part of the Zuzana ore field, the Žakarovce central gallery, photo St. Vassová • Hałdy i zachowane budynki kopalni położonej w środkowej części pola górniczego Zuzana, przy centralnej sztolni w Žakarovcach, fot. St. Vassová

in the Northern Europe where it was traded via Kraków, Toruń and Gdańsk, and from there across the Baltic Sea to Sweden, England and Flandern.

\section{Gelnica}

Initially, mines at Gelnica and surroundings were held by local people. The Hungarian monarchs invited colonists form Silesia, Rona and Bavaria after they realized the importance of gold, silver and copper exploitation.

Expansion of mining operations at Gelnica (Göllnitz) stimulated the arrival of German colonists from Bavaria, Dourine and Rona as early as in the XIIth and XIIIth centuries. In the year 1243, after devastating Tartar invasion that decimated local population the Hungarian King Béla IV issued the patent in which the arriving foreigners were guaranteed special rights and privileges. At that time Saxonians and Flemish colonists have arrived to the Spiš region.

Iura regalia granted to Gelnica by the Hungarian King Béla IV and liberties were extended by succeeding royal privileges issued in the years 1317, 1327 and 1343. As a result of successful exploitation of gold, silver, copper and iron ores, Gelnica has became a free mining town.

Profits from the mining operations were variable. Archival documents provide pieces of information about the highest production rates in the periods of prosperity, i.e. in the middle of the XVIth century and later, between the second half of the XVIIIth untill the end of the XIXth centuries.

\section{Smolník}

The first written remark on gold exploitation in Smolník comes from the year 1243, in the period just after the second Tartar invasion. The beginning of copper exploitation was documented even earlier, in the year 1225. Later on, mining operations shifted towards silver and iron ores. The Hungarian king Karol Robert d'Anjou decreed Smolník to become the mining town in 1332. In the year 1339 Smolník gained a higher court - three years earlier than the town of Košice. It is assumed that Smolník was the initial seat of the Mining Board, which function was later taken over by the Spiš Board.

From the document issued by the King Karol Robert in 1341 it can be concluded that Smolník had its own Chamber Count and Mining Mentor. In the XVIth century the mining

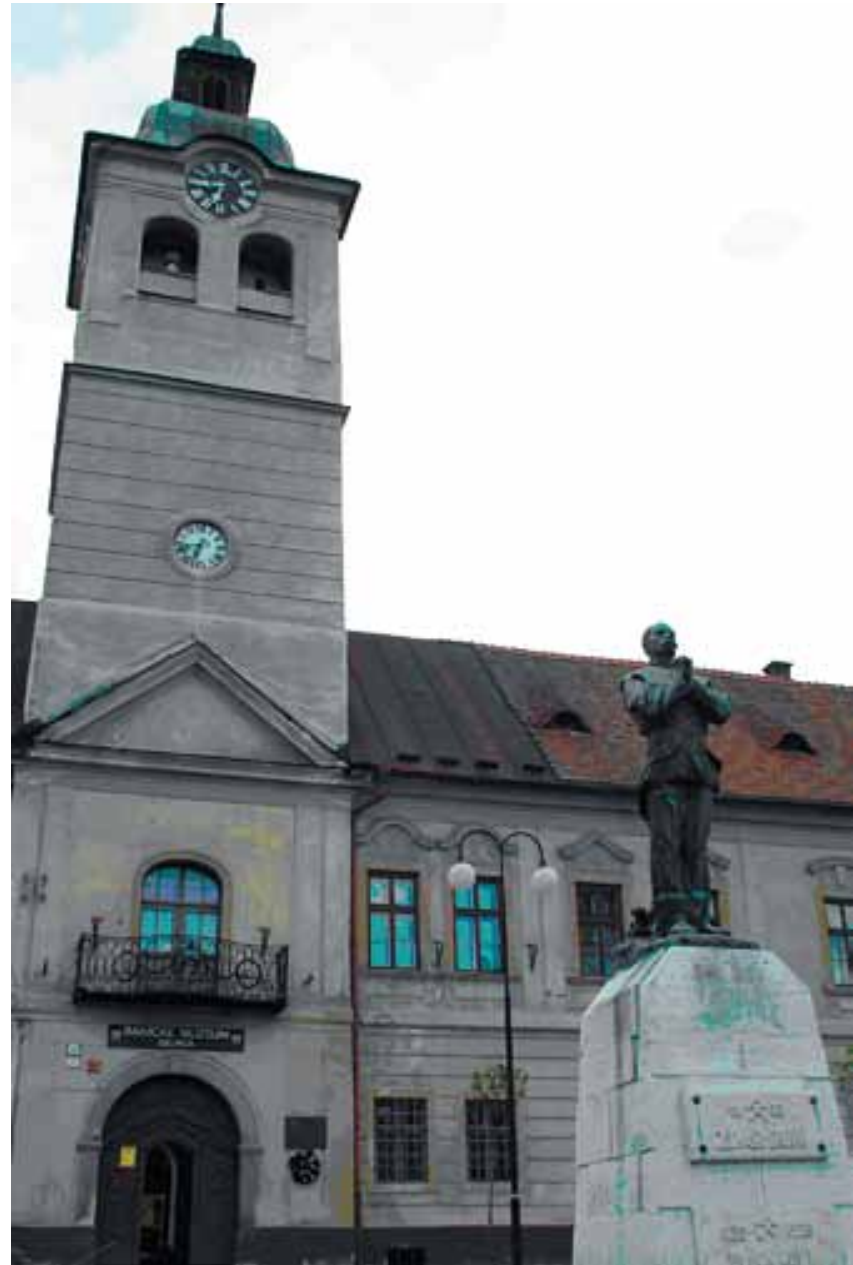

Fig. 8. Gelnica, Building of Mining Museum, photo P. Rybár • Gelnica, gmach Muzeum Górnictwa, fot. P. Rybár

operation expanded rapidly and Smolník's mint became wellknown for its coins.

In 1497, M. Thurso from Levoča applied a new technology of copper recovery by precipitating metal from mine drainage waters on iron slabs. It strongly raised the demand for water. The problem was solved with help of the Teresian gallery, which connected the Bystrý Potok stream flowing in the adjacent valley with the aquatic system of the Smolník valley. 


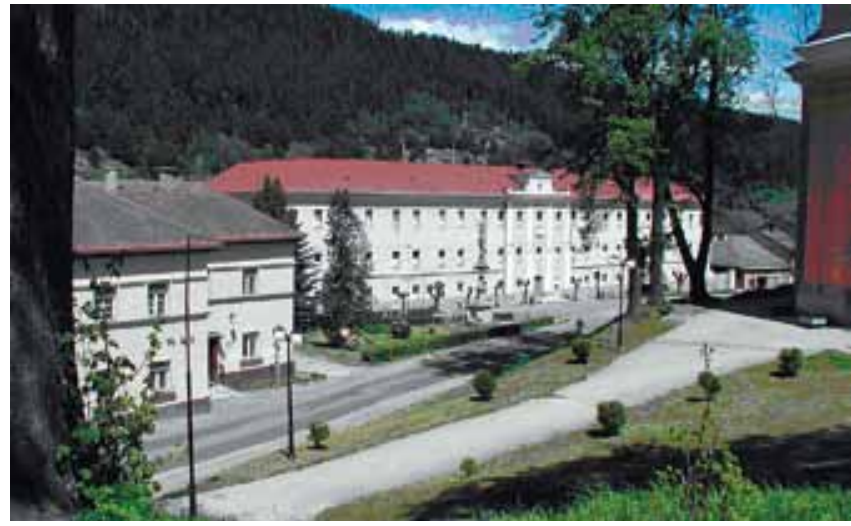

Fig. 9. The Kamerhof - the former seat of court chamber at Smolník destructed by fire in 1880 and reconstructed into tobacco factory, photo T. Sasvári • Kamerhof - dawna siedziba sądu w Smolníku zniszczona przez pożar w roku 1880 i przebudowana na fabrykę tytoniową, fot. T. Sasvári

Water needed as a driving force for machinery at the Smolník mines was also supplied by a reservoir located near Úhorná and connected with the Smolník mines by a 7,450 meters-long canal. Water was used for processing the ore, for driving drainage pumps and later for driving the power plant at Smolník.

Based on the proposal of Juraj Ernest Multz de Walda, the School of Mining was established in Smolník in the year 1747, as the result of educational activity of this leading mining expert. The school educated also mining administration staff and worked under the supervision of a chief inspector from the ministry. In the year 1762 both the chemistry and metallurgy courses has commenced. The Smolník Mining School had an extraordinary influence on development of mining industry in the Eastern Slovakia.
In the XVIIIth and the XIXth centuries the Smolník coper deposits belonged to the largest in Europe.

\section{Rožňava}

The first written reference to Rožn̆ava dates back to 1243 when processing of iron ore in this area was confirmed. In the next document issued in 1291 by the Hungarian king Andrew III exploitation of silver is mentioned.. The Hungarian royal decree issued in the year 1323 imposed a tax (so-called urbura) on gold mined in Rožňava. In 1382 Rožňava became the superior to the mining centers by the act of King L'udovít I.

The significant development of mining operations took place in the XVIth century. Primarily gold, silver and copper but also iron ores were worked in the region. The rich deposits of various ores ensured the hundreds-of-years-long mining activity in the Rožňava area. The last mine - Maria - was closed in 1992.

In the bishop's cathedral of Rožňava one can find a lateGothic masterpiece - an oil painting of unknown master (signed L.A.) from 1513 illustrating the life of Medieval miners. The $170 \times 125 \mathrm{~cm}$ painting shows Saint Anna (Metercia), Holy Mary, her daughter, and Jesus. In the background there are very realistic scenes of medieval exploitation and processing of silver and copper ores near Rožňava.

Saint Anna was the patron of all miners. This old tradition has been passed since the arrival of German miners in this area.

\section{Conclusions}

The retrospective excursion to the old ore mining districts was a success, also due to organizational efforts of the TUKE TRAVEL agency run by the Institute of Geotourism at the BERG Faculty of the Technical University of Košice. We are determined to revive this excellent event again in the Autumn, 2008.

\section{Streszczenie}

\section{Wycieczka geoturystyczna do wybranych miejsc historycznej eksploatacji złóż rud przez slowackich i niemieckich górników w rejonie Gelnicy-Smolníka, Słowacja}

\section{Pavol Rybár, Tibor Sasvári, Ladislav Hvizdák, Jana Hvizdáková, Bartolomej Baláž}

\section{Wstęp}

Wydział BERG Uniwersytetu Technicznego w Koszycach na Słowacji zorganizował spotkanie i wycieczkę śladami górników słowackich i niemieckich, pracujących w historycznych okręgach górnictwa rud Gelnica, Smolník i Rožňava.

W pierwszym dniu odbyła się uroczysta sesja $\mathrm{z}$ udziałem przedstawicieli przemysłu górniczego i uczelni górniczych ze Słowacji, Czech, Niemiec i Węgier. Zaszczycił ją swoją obecnością były Prezydent Republiki Słowackiej dr. Rudolf Schuster (Fig. 1, 2) oraz merowie okręgów Spiš i Gemer.
Następnego dnia uczestnicy wzięli udział w wycieczce do miejsc wspólnego dziedzictwa górników słowackich i niemieckich w okręgu Gelnica-Smolník district (Fig. 3b).

W pierwszej części wycieczka prowadziła z Gelnicy do Żakarovców, a następnie uczestnicy zostali przewiezieni do Smolnika, gdzie zwiedzali sztolnię terezjańską. Po obiedzie kontynuowano wycieczkę na trasie z Úhornej do Rožňavy. Późnym popołudniem uczestnicy wzieli udział w tradycyjnej ceremonii przyjęcia od stanu górniczego, zwanej “šachtág”.

\section{Budowa geologiczna}

\section{Rožňava}

W polu rudnym Rožňava, o powierzchni $48 \mathrm{~km}^{2}$, znajdują się 42 żyły rudne, z których 7 posiada zasoby rzędu 100 000 rudy (Grecula et al., 1995). Wyróżniający się w morfologii terenu grzbiet Košaricko-Turecká-Tri vrchy-Rakoš dzieli dolinę rzeki Slana i potoku Čučmianskiego na trzy części. Zachodnia część masywu Turecká zbudowana jest głównie z porfiroidów (metapaleoryolitów), natomiast jego północne zbocza budują fyllity i tzw. „,dolna jednostka wul- 
kaniczna“, zaś południowe stoki tworzą permskie piaskowce i iłowce jJednostki Gočaltov. Na wschód od rzeki Slana, w kierunku Čučmy pojawiają się utwory fliszowe (metapsamity i fyllity) dolnopaleozoicznej Jednostki Smolnika (Fig. 3b).

Żyły z tego rejonu zawierają głównie syderyt. Parageneza kwarc-syderyt-siarczki jest rzadka i spotykana tylko w niektórych żyłach (Artur-Terezia, Sadlovsky, Štefan, Kliment, Augusta and Siedma žila). W żyle "Mária" stwierdzono paragenezę kwarc-syderyt-siarczki wśród których występuje tetraedryt zawierający do $9.36 \%$ wag. srebra.

\section{Gelnicá}

Obszar Gelnica-Slovinky posiada trzy duże strefy żył: slovinską, gelnicką i Zláta žila (Złota żyła)-Helcmanovsky žilnik. Strefa gelnická obejmuje następujące żyły: Križová, Gelnická, Nadložná gelnická i Nová gelnická. Żyły zawierające masywne skupienia kwarcu, syderytu i chalkopirytu przecinają dolnodewońskie fyllity i porfiroidy (metapaleoryolity) należące do Formacji Drnava w obrębie Jednostki Gelnickiej (Fig. 5b).

Najpospolitszym minerałęm żyłowym jest kwarc. Rzadziej występuje grubokrystaliczny syderyt (z żyle Gelnickiej stosunek kwarc/syderyt wynosi 3:1), a towarzyszą im: ankeryt, Fe-dolomit i kalcyt. Wśród siarczków dominuje masywny chalkopiryt $\mathrm{z}$ domieszkami pirytu i tetraedrytu. Ten ostatni zawiera $0.4 \mathrm{wt} \% \mathrm{Ag}$, do $12.6 \mathrm{wt} . \% \mathrm{Hg}, 0.9-7.6$ wt.\% Fe i 1.1-5.3 wt.\% Zn (Pauliš and Duda, 2002).

Inna ważna strefa żyłowa znajduje się w okolicy Žakarovców. Ciągnie się na długości $5 \mathrm{~km}$ w kierunku E-W i ma 40-50 m grubości. Głównym minerałem rudnym jest syderyt, któremu towarzyszą Fe-dolomit i kwarc. Siarczki - chalkopiryt i tetraedryt - są rzadkie. Ruda $\mathrm{z}$ tego rejonu zawierała: $32-35$ vol.\% Fe, 0.1-0.2 vol.\% $\mathrm{Cu}$ i $8-12$ vol.\% $\mathrm{SiO}_{2}$

\section{Smolnik}

Złoże pirytowo-chalkopirytowe Smolnik znajduje się w centralnej części Gemerydów. Sylurskie formacje epimetamorficzne (zielone i czarne fyllity) przedzielone są horyzontem bazaltowo-keratofirowym. Ciało rudne, o rozciągłości E-W i długości $4 \mathrm{~km}$ zapada pod znacznym kątem $\left(70^{\circ}\right)$. Składa się na nie 10-11 horyzontów pirytowo-chalkopirytowych, których granice wyznacza zawartość brzeżna $\mathrm{Cu}$ (Fig. 5b). Najbogatsza mineralizacja kontynuuje się do głębokości $250 \mathrm{~m}$ poniżej powierzchni.

Głównym minerałem rudnym (20-90\%) jest drobnokrystaliczny lub masywny piryt oraz chalkopiryt. Zależnie od zawartości $\mathrm{FeS}_{2}$, występują rudy masywne, smugowane lub rozproszone. Chalkopiryt obecny jest we wszystkich odmianach. Cechą charakterystyczną jest wysoka zawartość Se w pirycie (do $200 \mathrm{ppm}$ ) i w chalkopirycie (do 512 ppm).

\section{Historia miast górniczych na obszarze Górnych Węgier}

Wspólne interesy doprowadziły do powstania w drugiej połowie XV wieku sojuszu pięciu wolnych miast królewskich we Wschodniej Słowacji. Były to: Košice, Levoča,
Bardejov, Prešov i Sabinov. Sojusz ten znany jest pod nazwą Pentapolitana lub Pentapolis.

Związek odgrywał znacząca rolę w ówczesnym handlu, gdyż kontrolował ważne skrzyżowanie dróg, wiodących z północy na południe i ze wschodu na zachód. Najważniejszym miastem były Košice, gdzie odbywały się regularne spotkania przedstawicieli miast członkowskich. Władcy, ministrowie królewscy i magnaci chętnie korzystali z dobrze zorganizowanej służby wywiadowczej i międzynarodowych kontaktów związku.

Ponadto instiały bardzo ścisłe związki i dobra współpraca między Pentapolis a tzw. Związkiem Miast Górniczych Górnych Węgier (Civitates Montanae Partium Superiorum). $\mathrm{Na}$ inauguracyjnym spotkaniu, które odbyło się w roku 1487 w Košicach postanowiono, że reprezentanci miast będą zasiadać i głosować w porządku ustalonym starymi tradycjami i przepisami, a także wartością produkcji górniczej: Gelnica, Smolník, Rudabánya, Jasov, Telkibánya, Rožňava, Spišská Nová Ves (Rudabánya i Telkibánya należą obecnie do Węgier).

\section{Historia górnictwa w obszarze Gelnica-Smolník}

Żywa jest nadal pamięć o polach górniczych Wschodniej Słowacji, gdzie wydobywano rudy złota, srebra, miedzi i innych metali ciężkich oraz żelaza. Dla przykładu, roczna produkcja miedzi w rejonie Smolnika w pierwszym trzydziestoleciu XV wieku wynosiła $182 \mathrm{t}$, ale już w wieku XIV tzw. "spisska miedź" zdominowała rynki w Europie Północnej, dokąd eksportowano ją przez Kraków, Toruń i Gdańsk, a potem przez Bałtyk do Szwecji, Anglii i Flandrii.

\section{Gelnica}

Na początku kopalnie w Gelnicy (Göllnitz) i w okolicy były własnością lokalnej społeczności. Władcy Węgier zaczęli sprowadzać kolonistów ze Śląska i Bawarii, gdy przekonali się jak ważna gospodarczo jest eksploatacja złóż złota, srebra i miedzi.

Rozwój górnictwa w Gelnicy już w wiekach XII i XIII zachęcał do przybycia kolonistów z różnych części Niemiec. W roku 1243, po niszczącym najeździe tatarskim, który zdziesiątkował mieszkańców tego regionu król Węgier Béla IV wydał dekret gwarantujący specjalne prawa i przywileje obcokrajowcom osiedlającym się w okolicy. Wtedy przybyli na Spiš pierwsi koloniści z Saksonii i z Flandrii.

Iura regalia nadane przez króla Bélę IV i związane z tym przywileje zostały rozszerzone przez kolejne nadania królewskie w latach 1317, 1327 i 1343. Dzięki zyskownej eksploatacji rud złota, srebra, miedzi i żelaza Gelnica otrzymała status wolnego miasta górniczego. Okresy szczególnej prosperity to połowa wieku XVI oraz okres od drugiej połowy XVIII do końca XIX wieku.

\section{Smolník}

Pierwsza pisana wzmianka o Smolníku i o eksploatacji złota pochodzi z roku 1243, z okresu zaraz po napadzie Tatarów. Początki wydobycia miedzi są jeszcze wcześniejsze, bo datują się na rok 1225. Potem wydobywano głównie rudy 
srebra i żelaza. Miastem górniczym uczynił Smolník król Węgier Karol Robert d'Anjou w roku 1332, a w roku 1339 miasto otrzymało własny sąd - trzy lata wcześniej od Košic. Przypuszcza się, że to własnie Smolník był pierwotnie siedzibą Urzędu Górniczego, zanim jego obowiązki przejęła Rada Spisska. W wieku XVI-tym, gdy Smolník przeżywał okres rozwoju, sławna stała się mennica.

W roku 1497 niejaki M. Thurso z Levočy zastosował nowa metoda odzysku miedzi z wód kopalnianych poprzez wytrącanie metalu na żelazie. Spowodowało to wzrost zapotrzebowania na wodę. Problem rozwiązało przebicie sztolni terezjańskiej, która połączyła Bystrý Potok płynący w sąsiedniej dolinie z systemem wodnym doliny Smolníka.

Wodę niezbędną do poruszania urządzeń przeróbczych, pomp odwadniających w kopalniach Smolníka, a później także do napędzania elektrowni uzyskiwano także ze sztucznego zbiornika, położonego niedalego miejscowości Úhorná i połączonego z kopalniami kanałem o długości $7450 \mathrm{~m}$.

W roku 1747 założono w Smolníku Szkołę Górniczą, w oparciu o propozycję Juraja Ernesta Multz de Walda, eksperta górniczego, który prowadził tu działaność edukacyjna. Obok górników szkoła kształciła także pracowników administracji górniczej. Nadzorował ją inspektor z ministerstwa. W roku 1762 dodano także kształcenie w zakresie chemii i metalurgii. Szkoła w Smolníku miała niezwykle istotne znaczenie dla rozwoju górnictwa we Wschodniej Słowacji.

W wiekach XVIII i XIX złoża miedzi w Smolníku należały do największych w Europie.

\section{Rožňava}

Pierwsze wzmianki o Rožňavie ukazały się w dokumencie $\mathrm{z}$ roku 1243, potwierdzającym wydobycie rud żelaza w tym rejonie. Następny dokument, wydany przez króla Węgier Andrzeja III w roku 1291, wspominał o wydobyciu srebra. Królewski dekret z roku 1323 nakładał podatek (tzw. urbura) od produkcji złota. W roku 1382 król Ludwik I uczynił Rožňavę zwierzchnikiem wszystkich miast górniczych.

Okres wielkiego rozwoju okręg przeżywał w wieku XVItym, gdy wydobywano tu rudy złota, srebra, miedzi i żelaza. Eksploatacja bogatych złóż trwała kilka wieków - ostatnią kopalnię o nazwie „Maria” zamknięto w roku 1992.

W katedrze biskupiej w Rožňavie znajduje się późnogotycki obraz olejny z roku 1513, pędzla nieznanego artysty, podpisanego jedynie inicjałami L.A. Przedstawia on Św. Annę, jej córkę Maryję i małego Jezusa, zaś w tle namalowano bardzo realistyczne sceny z życia i pracy górników z kopalń rud srebra i żelaza wokół Rožňavy.

Św. Anna została patronką wszystkich górników. Ta stara tradycja datuje się od przybycia na te tereny niemieckich gwarków.

\section{Literatura (References)}

Batta, Š. 2001: Rožňavská Metercia. Banícke múzeum v Rožňave,. pp. 13 Biely, A., Bezák, V., Elečko, M., Kaličiak, M., Konečný, V., Lexa, J., Mello, J., Nemčok, J., Potfaj, M., Rakús, M., Vass, D., Vozár, J., Vozárová, A., 1996. Geological map of Slovakia, 1: 500,000 scale. Ministry of the Environment, Bratislava, 1996.
Maderspach, L. 1876: Der Bergbau von Zsakóc in der Zips. Österr. Z. Berg.u. Hüttenwes. (Wien), 24, 175-177.

Papp, K. 1919: Die eisenerz- und kohlenforräte des Ungarischen Reiches. Budapest, Franklin-Vereins, pp. 638. 